\title{
MUSCLE HISTOLOGY IN RHEUMATIC AND CONTROL CASES : A STUDY OF ONE HUNDRED AND NINETEEN BIOPSY SPECIMENS
}

\author{
BY \\ M. H. L. DESMARAIS, H. J. GIBSON, and G. D. KERSLEY
}

From the Royal National Hospital for Rheumatic Diseases, Bath

\section{Introduction}

Our conception of the pathology of rheumatoid arthritis has become modified as the result of recent studies of the widespread changes taking place in the non-articular tissues in this disease. Gibson and others (1946) confirmed the work of Freund and others (1945) by showing that the affected tissues were all of mesodermal origin and that the lesions found in muscles consisted of a perivascular roundcell reaction in the endomysium and of a paravascular cell reaction in the fibrous supporting connective tissue. The blood vessels were sclerosed, with proliferation involving all three coats, and a cell infiltration, almost entirely lymphocytic in type, appeared to originate in the adventitia and to spread outwards. The individual muscle fibres showed evidence of degeneration. This range in degree from loss of striation, longitudinal fissuring, and vacuolation, to the formation of scar tissue enclosing degenerated shrunken muscle fibres. Muscle-fibre degeneration was frequently more marked near the cellular infiltrations.

It was suggested that the relationship of the reaction to the blood vessels might indicate that the noxious agent was a blood-borne irritant, but there was no evidence to show whether or not it was infective in origin. de Forest and others (1947) reported the presence of muscle lesions in twelve out of sixteen cases of rheumatoid arthritis, and in two of four controls of "non-specific infectious" arthritis. They could find no relation between the presence of the lesions and the duration or activity of the disease. Thirteen other controls, consisting of cases of osteo-arthritis, rheumatic fever, gonococcal arthritis, and "non-specific infectious arthritis" failed to show the muscle lesions as seen in rheumatoid arthritis.
Since our previous communications (Gibson and others, 1946; Kersley and others, 1946) further examinations of material obtained either by biopsy or at operation have been carried out on a series of fifty-six typical cases of idiopathic rheumatoid arthritis, five of non-specific infective arthritis, fortythree other rheumatic conditions, and fifteen nonrheumatic controls.

\section{Methods}

The biopsies were taken under local anaesthesia either from the deltoid or the quadriceps muscles, and in two cases from the erector spinae muscle. The material collected at operation was excised from the vastus externus in cases of arthrotomy and knee lavage, and from the vastus internus when a synovectomy was performed. The muscle excised did not always show evidence of wasting clinically, and the neighbouring joints were not necessarily affected.

The amount of muscle taken was sufficient to give a stained section of approximately $13 \mathrm{~mm}$. by $8 \mathrm{~mm}$. on the average, although the actual size varied considerably with the circumstances of its removal. Portions removed at operation under general anaesthesia were larger than those taken under local anaesthesia.

Many fixatives were used including Zenker, formol sublimate, and 5 per cent. formol saline. Zenker was best, but the results with 5 per cent. formol saline were -quite satisfactory. The tissue was then passed through industrial spirit, acetone, and benzene, and embedded in the vacuum bath. The routine stain was iron haematoxylin and eosin. Other stains used in certain cases were Masson's trichrome, Foot's reticulin stain, and Unna-Pappenheim stain for plasma cells.

In order to obtain an unbiased assessment of the experimental findings the cases were carefully examined clinically and grouped according to a tentative classification. The biopsy material was reported on by the pathologist without knowledge of the clinical findings. The pathological and clinical data were later correlated. 
The sedimentation rate and haematocrit were estimated by the method of Collins and others (1940). The corrected suspension stability (C.S.S.) is the percentage volume of red cells after one hour corrected for any anaemia present, taking a haematocrit reading of 42 per cent as being normal. A corrected suspension stability of 85 per cent. or more is taken as normal, and a reading below 60 per cent. is considered maximal.

\section{Classification and Definition}

Cases of non-specific polyarthritis were divided into two groups:

1. Typical idiopathic rheumatoid arthritis;

2. Non-specific infective arthritis.

The idiopathic type is liable to affect the young adult or middle-aged individual. It is five times more common in women than in men and usually occurs between the ages of 15 and 45 . It is characterized by general constitutional and autonomic disturbances, accompanied sometimes by a low fever. There is early muscle wasting, the sedimentation rate is raised, and anaemia is present. Generalized osteoporosis is an early sign. The polyarthritis tends to effect symmetrically the smaller peripheral joints first, and to spread to the other joints later. If untreated it ends in contractures, subluxations, and ankyloses.

In the non-specific infective type the occurrence in men is less rare. The age incidence has a wider range. The onset is sometimes acute and often follows an infection in the sinuses or the throat, an apical abscess, or a pelvic condition. The larger joints tend to be affected earlier than the smaller and the joint involvement is less symmetrical. The sedimentation rate has a tendency to fluctuate, and there may be little loss of weight. If a focus of infection is found and dealt with, the prognosis is usually good. The osteoporosis is not generalized but is more evident at the site of the involved joints. It must be remembered, however, that there exist all gradations between the two types, and especially in the later stages differentiation may be very difficult. Whenever there was doubt the case was included in the idiopathic rheumatoid arthritis group.

\section{TyPiCAL IDIOPATHIC RheumatoId ARTHRItIS}

Of fifty-six cases of typical idiopathic rheumatoid arthritis investigated, 34 (60.7 per cent.) showed round-cell foci and blood-vessel changes. Twentytwo out of thirty-eight men of ages varying from 15 to 65 years, and twelve out of eighteen women of ages varying from 35 to 56 years were positive. The bigger number of males in this series was due to the fact that it was easier to obtain their consent to have a biopsy done. The size of the sections varied between $6 \times 8$ and $20 \times 10$ millimetres, the average being $13 \times 8$ millimetres wide. The fact that the lesions were found in such small specimens in as high a proportion as 60.7 per cent. is an indication of their widespread distribution.

In one case two small foci were seen on the very edge of the section, and when further serial sections were made from the same block at a different level no other foci could be demonstrated. Had the muscle specimen been slightly smaller or been taken from a different site the histo-pathological changes found might have been absent and a negative report would have been sent by the pathologist. This indicates the importance of the sampling error in assessing results.

Several cases which were clinically and radiologically typical of idiopathic rheumatoid arthritis with varying degrees of muscle wasting showed histologically marked degenerative changes in the muscle fibres but the typical round-cell foci were not present. These cases were included in the negative group.

Relationship of Positive Findings to Activity.The changes in the muscles were present not only in cases in which the disease was active but also in those which appeared clinically quiescent or " burnt out ", as judged by the absence of resting pain and anaemia, constant weight or gain in weight, and

TABLE 1

RELATIONSHIP OF FINDINGS TO ACTIVITY

\begin{tabular}{c|c|c|c|c}
\hline Findings & $\begin{array}{c}\text { Number } \\
\text { of } \\
\text { cases }\end{array}$ & $\begin{array}{c}\text { No } \\
\text { anaemia }\end{array}$ & $\begin{array}{c}\text { Normal } \\
\text { C.S.S. }\end{array}$ & $\begin{array}{c}\text { No } \\
\text { anaemia } \\
\text { and } \\
\text { normal } \\
\text { C.S.S. }\end{array}$ \\
\hline $\begin{array}{l}\text { Positive } \\
\text { Negative }\end{array}$ & 34 & $11(32 \cdot 3 \%)$ & $\begin{array}{c}5(14 \cdot 7 \%) \\
4(18 \cdot 1 \%)\end{array}$ & $\begin{array}{l}3(8 \cdot 8 \%) \\
3(13 \cdot 6 \%)\end{array}$ \\
\hline
\end{tabular}

normal sedimentation rate. Table 1 shows the number of negative and positive biopsies in such cases. Two cases could be quoted: One showed marked muscle wasting and the other no wasting of the muscle from which the biopsy was taken, but both were of long standing and apparently " burnt out". Each showed the round-cell foci as seen in rheumatoid arthritis.

CASE 77.-A farm worker, aged 41, gave a history of rheumatoid arthritis of 15 years' duration. All the joints except the hips and spine and to a very slight extent the knees, were involved. The quadriceps from which the biopsy was taken showed no clinical evidence of wasting. There was no anaemia, and the sedimentation rate was normal. There were no joint pains. He 
had had several courses of gold with fairly good results. The weight had remained constant for many years. Radiographs of the hands showed changes of rheumatoid type, with secondary osteo-arthritis. The muscle biopsy was taken from the right vastus externus and a section showed the typical changes consistent with rheumatoid arthritis (Fig. 1).

CASE 10.-A housewife, aged 56, had typical rheumatoid arthritis of 24 years' duration with marked muscle wasting. She had had two courses of gold with good results. Recently she had much improved and was gaining weight and had no pain in her joints even on movement. There was no anaemia, and the sedimentation rate was normal. Radiographs of the hands showed changes of rheumatoid type with secondary osteoarthritis. The muscle biopsy was taken from the left vastus externus, and on section again several round-cell foci were seen.

Relationship to Wasting.-The lesions were not found only in cases in which muscle wasting was present. Two cases, with good muscular power, full range of movements of the hip and knee joints, and no clinical evidence of wasting of the quadriceps, showed changes consistent with rheumatoid arthritis. One had typical rheumatoid arthritis of 15 years' duration which had become relatively quiescent as judged by the absence of anaemia, lack of joint pains, and $x$-ray evidence of superadded secondary osteo-arthritic changes in the joints of the hands.

The other was of 4 years' duration and was still active at the time of the biopsy.

Relation to duration.-An attempt was made to correlate the frequency of positive findings with the duration of the disease. The accompanying graph shows that no typical rheumatoid changes were found in cases of less than 6 months' duration. In those examined within three years, seven years, and from 8 years onwards the chances were 47 per cent., 66 per cent., and 82 per cent. respectively. The lesions were present in cases of from one to 24 years' duration.

Relation to other Morbid Histological Findings. In two cases muscle biopsies were negative, yet there were other positive morbid histological findings. The first case showed no lesions in the muscle, but two subcutaneous nodules excised from the elbows were typical of rheumatoid arthritis. In the second case the muscle specimen was also negative but the synovia showed Allison and Ghormley round-cell foci.

CASE 100.-A housewife, aged 31, had typical rheumatoid arthritis of 7 years' duration. Her knees had never troubled her much and the quadriceps were not wasted. Her weight had remained constant but she was anaemic and the sedimentation rate was raised (C.S.S. 71 per cent.). The muscle biopsy from the vastus externus showed no round-cell foci and very little muscle degenera-

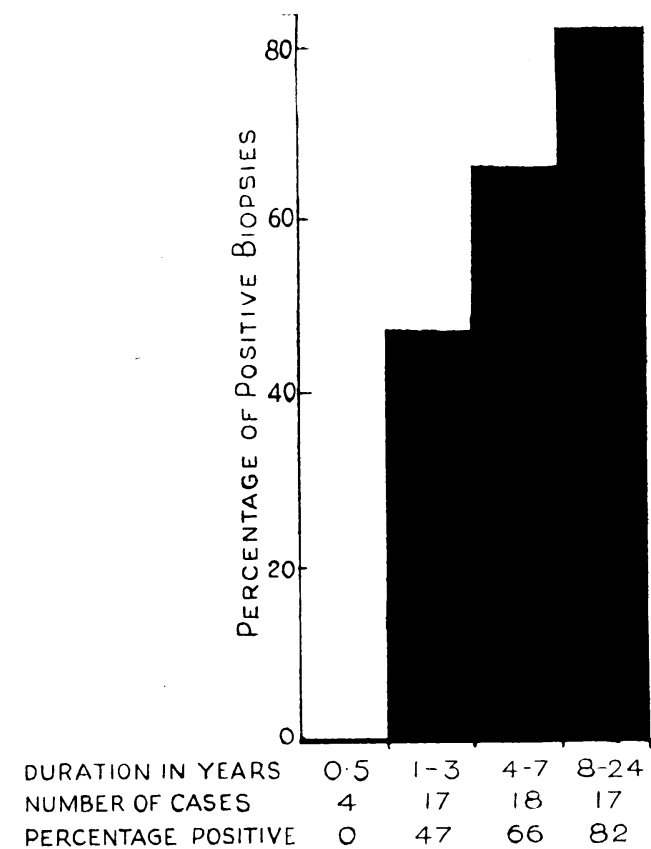

GRAPH showing relationship between duration of disease in years and percentage of positive biopsies.

tion, but two large subcutaneous nodules excised from the elbows showed the changes typical of rheumatoid arthritis.

CASE 83.--An ex-miner, aged 57, had been suffering from rheumatoid arthritis for two years, during which time he had lost nearly 2 stone in weight. There was no anaemia (haematocrit 42 per cent.) but the sedimentation rate was raised (C.S.S. 60 per cent.). The plasma uric acid was $5 \mathrm{mg}$. per cent., and the Kahn test was negative. The $x$-ray appearances of the hands were of the rheumatoid arthritic type. Muscle and synovial material collected at operation for bilateral knee lavage were both negative. The synovia showed a non-specific chronic inflammatory reaction with diffuse round-cell infiltration but no foci of the Allison and Ghormley type. When a synovectomy on the right knee was performed 5 months later the synovia showed an extremely active round-cell reaction with, in certain of the villi, localized lymphocytic accumulations as seen in rheumatoid arthritis.

The findings in this last case are of interest in view of the report by McEwen and others (1941). Using the supravital method of staining they examined synovial tissue from cases of tuberculous and rheumatoid arthritis and also from cases with traumatic joint disturbances and synovitis of unknown cause and from two cases of poliomyelitis. In all these cases small and medium size fixed tissue cells were demonstrated. Bennett 
(1941) studied 155 cases of arthritis and showed that a chronic inflammatory reaction, which frequently contained no diagnostic features, could be demonstrated in the synovia, and he came to the conclusion that the finding of lymphoid accumulations with or without germinal cells was not specific for rheumatoid arthritis.

Seventeen of the thirty-four typical rheumatoid arthritic patients with positive muscle findings showed other positive histo-pathological changes also.

TABLE 2

RELATIONSHIP OF POSITIVE AND NEGATIVE MUSCLES TO OTHER MORBID HISTOLOGY FINDINGS

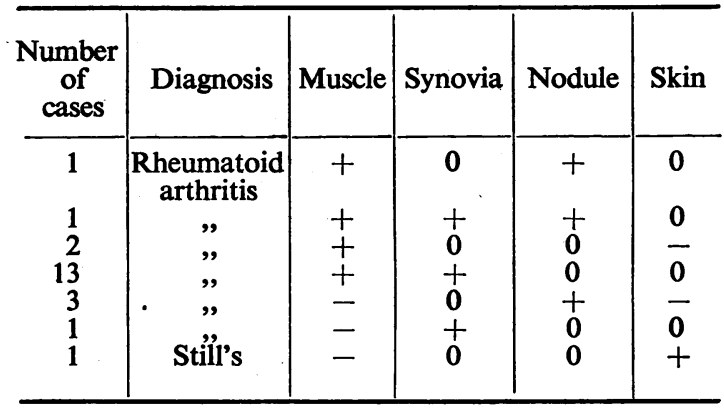

$0=$ not examined.

Table 2 illustrates these findings. In some cases biopsies from two different sites were taken. In one the deltoid showed no changes but the quadriceps gave a positive result, and in the other both the quadriceps and the deltoid muscles showed the presence of round-cell foci.

Curtis and Pollard (1940) were the first to describe small perivascular infiltrations with lymphocytes in the corium of the skin in cases of rheumatoid arthritis and Felty's syndrome. In two cases with positive and three with negative muscle findings, the skin appeared normal. However, in a case of Still's disease (Case 72) though the underlying muscle appeared normal there were several areas of perivascular round-cell infiltration in the corium. The cells were lymphocytes and in each focus as seen in the stained section fifty or more were seen in the interstices of a fine network of collagen fibrils. In one instance such a focus was adjacent to a bundle of arrectores pilorum muscles. It appeared to be eroding the muscles, displacing and breaking up the fibres, fragments of which could be seen within the focus in Masson-stained sections (Fig. 2).

Rheumatoid Arthritis with a Past History of Rheumatic Fever.-Four cases of rheumatoid arthritis gave a history of previous attacks of rheu- matic fever, one of which showed typical round-cell foci, and another evidence of an early focus in the muscle examined.

CASE 71.-A woman, aged 46 , had had two attacks of rheumatic fever at the ages of 10 and 21. The heart was not involved. At the age of 30 she had had a third attack, which was soon followed by permanent joint changes, flexion deformity, and stiffening of the fingers wrists, elbows, and knees. There was marked. muscle wasting. Previous to admission she had had an attack of herpes zoster of the right leg accompanied by an exacerbation of the joint pains. The haematocrit was 33 per cent. and the sedimentation rate raised (C.S.S. 67 per cent.). The $x$-ray appearances of the hands were typical of rheumatoid arthritis with secondary osteoarthritic changes. The histological appearances of the muscle are figured in our earlier paper (Gibson, Kersley and Desmarais, 1946, Fig. 3).

CASE 42.-A woman, aged 32, gave a history of three attacks of rheumatic fever at the ages of 14, 22, and 25. The heart was again normal. Soon after the third attack she developed the typical changes of rheumatoid arthritis. There was marked muscle wasting with moderate deformity. She had had fourteen courses of gold but developed toxic symptoms with the last. The haematocrit was 35 per cent. and the sedimentation rate was normal (C.S.S. 89 per cent.). It is interesting to note that this patient too, had had an attack of " shingles" at the age of 22. A muscle biopsy was done on the left deltoid and the section showed histological evidence of early foci. The muscle showed very slight degenerative changes and no arterial disease was seen. Two very small foci were found. One was adjacent to an arteriole in the intermuscular fibrous tissue, and the other was in an endomysial position. They consisted of five to ten lymphocytes with proliferation of local fibroblasts. No polymorphs, plasma cells, or large mononuclear cells were present. Although small in size, these foci were suggestive of an early rheumatoid reaction.

Rheumatoid Arthritis and Psoriasis.-Four cases were associated with psoriasis and only one gave a positive muscle result. In two cases where no histological changes other than non-specific muscle degeneration were found the psoriasis had been present for five and seven years respectively before the onset of the arthritis; in the third case the psoriasis started four years after the onset of the polyarthritis, and this patient also showed no changes in the muscles.

CASE 76.-The fourth patient was a bath attendant, aged 57, who had had psoriasis for 27 years with exacerbations and remissions. Three years before admission, soon after an accident, he developed polyarthritis. He had lost 2 stone in weight since the onset of the arthritis. An attempt to treat him with gold caused the psoriasis to get worse. There was no anaemia and the sedimentation rate was normal. The $x$-ray appearances were typical of rheumatoid arthritis with secondary osteo-arthritis. 
Section of muscle showed degenerative changes with proliferation of nuclei. The vessels were sclerotic. Two foci of rheumatoid type were present in relation to small vessels lying deeply among the muscle fibres. Both showed lymphocytes, plasma cells, and a few phagocytic large mononuclear cells. They were in all respected similar to the smaller foci noted in clinically typical rheumatoid cases.

Rheumatoid Arthritis and Gonococcal Infection.None of the seven cases of chronic polyarthritis included in this group showed the histological changes seen in rheumatoid arthritis. All gave a history of a gonococcal urethritis from 12 and 28 years before the onset of the arthritis. In two cases gonoccocal arthritis was suggested by the history of pain in and swelling of the heels and sternoclavicular joints, the asymmetry of the joint involvement and the absence of changes in the joints of the hands. The complement fixation test and prostatic massage, however, revealed no evidence of a gonococcal infection. Two cases were typical gonococcal polyarthritis. They both gave a history of a gonococcal urethritis followed within four and six weeks respectively by acute polyarthritis. From all these cases negative results were obtained on biopsy.

\section{Cases other than Rheumatoid Arthritis}

Still's Disease.-Of three cases of Still's disease, two failed to show the changes; one case showed highly characteristic round-cell foci in the muscle, and another showed changes in the skin.

CASE 72.-A farmer's daughter, aged 21, gave a history of rheumatic fever at the age of 10 . After a recurrence at the age of 13 she developed permanent joint changes with marked wasting, flexion deformity, and painful fibrous ankylosis of the elbows, hips, knees, and ankles. She had had four courses of gold without any improvement. Her heart was not involved. There was marked anaemia (haematocrit 35 per cent.), and the sedimentation rate was raised (C.S.S. 55 per cent.). The $x$-ray appearances of the hands showed rheumatoid changes. A biopsy of the quadriceps showed only non-specific muscle degeneration but no foci. The skin, however, showed the changes described earlier in this paper and depicted in Fig. 2.

Subacute Rheumatic Infection.-Four cases of subacute rheumatic infection with cardiac involvement, but with no permanent joint changes, failed to show any changes in the muscles. However, one case with a negative muscle finding showed changes in the skin.

CASE 21.-A housewife, aged 37, gave a history of frequent attacks of pharyngitis and tonsillitis at the age of 18. One month after the last attack there was a sudden onset of fever and the appearance of painful swellings in both Achilles tendons. She was treated as a case of rheumatic fever and hospitalized for six months. She remained quite well for 4 years when she developed another attack of tonsillitis followed by pain and slight swelling of her knees and hands which lasted for six weeks. She remained symptom free for eight years. In 1946 she had another attack of tonsillitis associated with ? erythema nodosum. From that date she began to gain weight, and put on 3 stone in 3 years. On admission she was grossly overweight and presented the features of a case of panniculitis. The joints were not involved. There was a soft systolic murmur at the apex which did not vary with changes of posture, and she had fair tolerance to exercise. The haematocrit was 46 per cent. The sedimentation rate was increased (C.S.S. 78 per cent.), and the plasma uric acid was $3.8 \mathrm{mg}$. per cent. The skin and subcutaneous tissues were excruciatingly painful and she bruised easily. The muscle was negative but the skin showed the presence of perivascular round-cell foci in relation to the cutaneous vessels, the appearances very similar to those previously noted in skin covering subcutaneous nodules in rheumatoid arthritis.

Rheumatic Fever.-One case of a boy, aged 15 , suffering from rheumatic fever with gross cardiac enlargement, a double mitral lesion, and multiple subcutaneous nodules did not show the changes in the muscles met with in rheumatoid arthritis.

Non-specific Infective Arthritis.-Four cases showing atypical features could not be included in the idiopathic rheumatoid arthritis group and will be described in detail. One case gave positive findings in both muscle and synovia. Two showed changes consistent with rheumatoid arthritis in the synovia but the muscle sections were negative, and in the fourth the muscle was negative but the synovia was not examined.

CASE 57.-In 1942 at the age of 29 a housewife, directly after the Bath blitz, noticed a sudden pain and swelling of both her knees. The left knee improved after a few weeks but the right knee became progressively worse. No other joints were affected. In 1945 the right knee was swollen and painful and the synovial membrane appeared thickened. Repeated aspirations produced no improvement. An arthrotomy and knee lavage was performed but with only temporary benefit. In 1945 a synovectomy revealed a very thickened synovium. The haematocrit was 41 per cent. and the blood sedimentation rate was maximal (C.S.S. 62 per cent.).

The section showed an extensive degree of muscle degeneration and fibrosis. Certain areas consisted of dense fibrous tissue with small atrophic muscle fibres still persisting within it. The vessels showed advanced sclerosis. In some of the small arterioles the lumen was, almost obliterated. One perimysial focus of round cells was seen. It involved the adventitial coat of a small vessel and consisted of lymphocytes with scanty neutrophil polymorphs and large mononuclear cells. The findings were fully consistent with rheumatoid arthritis. 


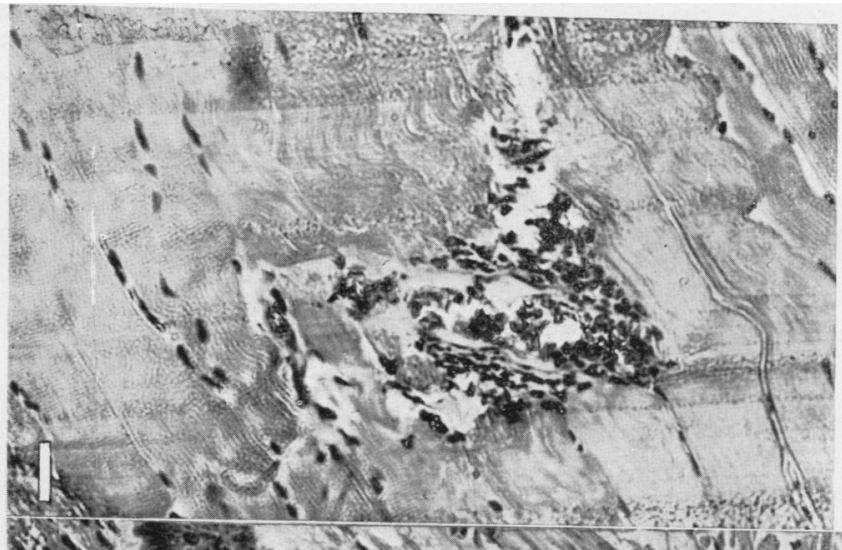

FIG. 1.-Quadriceps muscle from a typical case of idiopathic rheumatoid arthritis showing a perivascular round-cell focus. (Haematoxylin and eosin $\times 100$.)

Fig. 2.-Skin from a case of Still's disease. Focus of round-cell reaction involving an erector pilae muscle. (Haematoxylin and eo$\sin \times 100$.)
FIG. 3.-Muscle and fibrous tissue from Volkmann's ischaemia showing muscle degeneration with fibrosis with diffuse round-cell infiltration of fibrous tissue. (Haematoxylin and eosin 100.) 


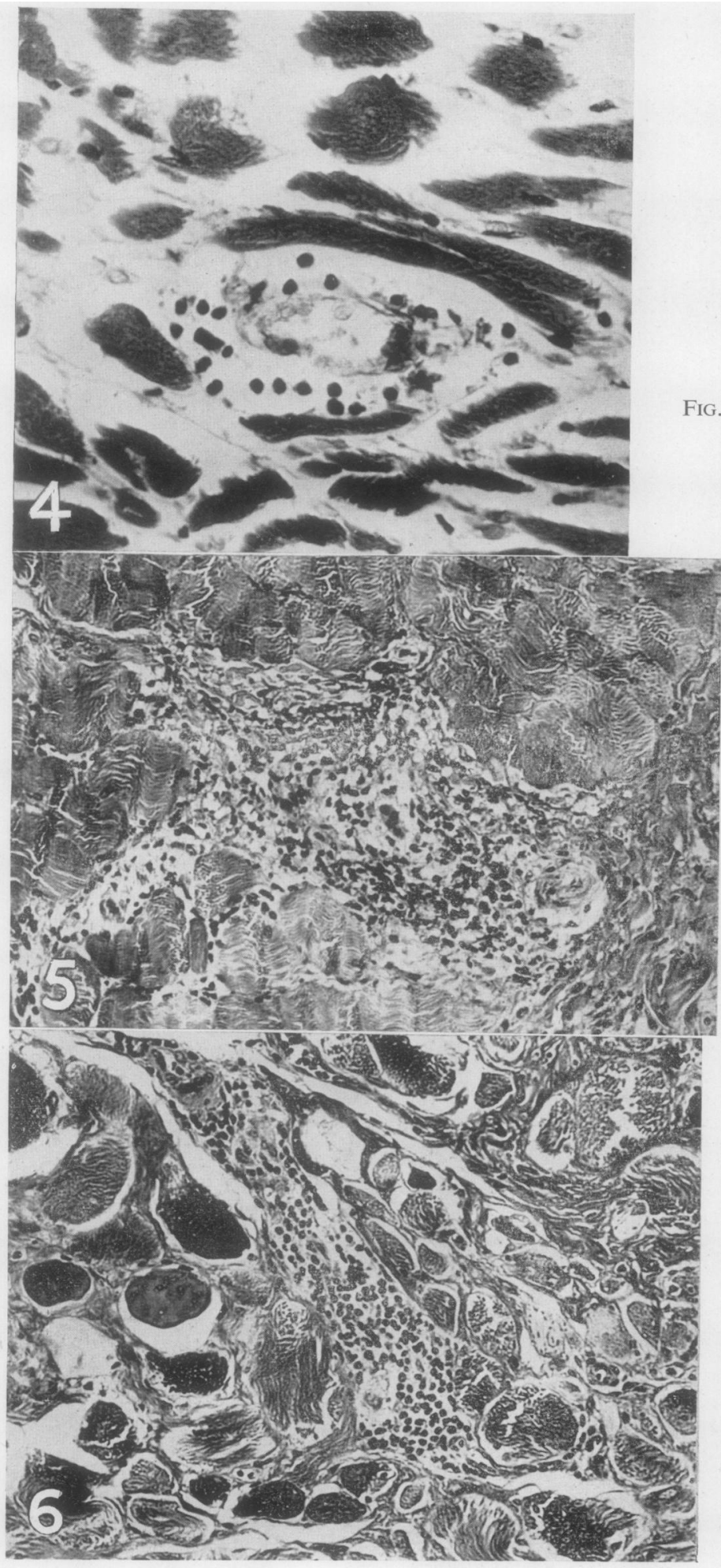

FIG. 4.-Quadriceps muscle from a case of spinal tuberculosis causing paraplegia. Very scanty lymphocytes in relation to vessel. (Haematoxylin and eosin 400.)

FIG. 5.-Muscle from a case of myositis of unknown origin. No evidence of rheumatism was present. Interstitial round-cell (lymphocytic) infiltration of muscle. (Haematoxylin and eosin $\times 100$.)

FIG. 6.-Muscle underlying site of foreign-body reaction following removal of breast. Muscle shows degeneration and fibrosis with round-cell reaction simulating that of rheumatoid arthritis. (Haematoxylin and eosin $\times 100$.) 
CASE 104.-In 1943 a male, aged 36, felt a sudden sharp shooting pain in his left hip in stepping off a kerb. The pain seemed to spread all over his body. There was no fever and no sore throat. He was in bed for 19 weeks. The pain and swelling settled in the right ankle and right knee. There had never been any loss of weight and there was no history of past infection. In 1945 the left knee, the feet, and ankles became painful and swollen. His general condition was good but there was marked wasting of the lower right limb. In 1947 the pain and swelling in the knees had become worse. There was marked synovial thickening and a moderate effusion was present. The haematocrit was 35 per cent. and the blood sedimentation rate was maximal (C.S.S. 57 per cent.). Radiographs of the hands, which clinically were not affected, showed changes presumptive of rheumatoid arthritis. A bilateral knee lavage was performed and two specimens of muscle and synovia were excised for examination. Both muscle biopsies failed to show the changes described previously, but the synovial changes were consistent with rheumatoid arthritis.

CASE 2.-A male, aged 20, gave a history of gradual onset of swelling of both his knees in 1946. There had been no history of trauma or infection. At about the same time he had experienced pain and swelling of the first metacarpo-phalangeal joints. There was nothing relevant in the family history, and the Kahn reaction was negative. On admission the knees were found to be grossly unstable with bilateral effusion and synovial thickening and moderate wasting of the quadriceps. There was no anaemia, the haematocrit being 42 per cent., and the blood sedimentation rate was normal (C.S.S. 90 per cent.). Radiographs of the hands showed evidence of very early osteoporosis. A bilateral arthrotomy and knee lavage was performed and the specimen of muscle from both vasti showed no changes, but accumulations of lymphocytes were found in the synovia.

CASE 32.-A labourer, aged 57, gave a history of an injury to the right hip 15 years ago. In 1944 he was discharged from the Marine Police with arthritis of the right hip. One year later he noticed pain in and limitation of movements of the right shoulder. He was given a full course of gold with moderate improvement. On admission the haematocrit was 41 per cent. and the blood sedimentation rate was maximal (C.S.S. 59 per cent.). The plasma uric acid was $4.7 \mathrm{mg}$. per cent. Apart from the hip and the right shoulder, all the other joints appeared normal. Radiographs of the hands showed nothing abnormal.

A biopsy from the right vastus externus showed no round-cell foci and no definite evidence of degenerative changes in the muscle.

In addition the following material was seen which, while not sufficiently similar to cause confusion, showed features common to some seen in rheumatoid arthritis. Muscle and synovial membrane collected at operation from a young girl aged 14 with a history of chronic pain and swelling of the right knee of unknown aetiology showed no abnor- mality in the muscle but changes in the synovia of non-specific type.

Spondylitis Ankylopoietica.-Muscle biopsies in seventeen cases of spondylitis ankylopoietica were examined and in all specimens the result was negative.

In three cases the material was collected from the deltoid muscle. There was no muscle wasting in the upper limbs and the shoulders and peripheral joints were not involved. In twelve cases the biopsy was taken from the quadriceps. Of these, five cases showed muscle wasting ranging from slight to very marked degree. The knees and hips were involved in one case.

In seven cases no evidence of quadriceps wasting was present, the condition being limited to the spine and sacro-iliacs only. In two cases the muscle was collected from the erector spinae in the lumbar region, the site most affected.

Gout.-Muscles from five cases of typical gout were examined and were negative. The biopsy was taken from the quadriceps in five cases and from the right deltoid in one. Two cases were of advanced tophaceous gout and showed marked quadriceps wasting with involvement of the knee joints. One case which might be considered one of atypical gout showed on biopsy mild degenerative muscle changes only.

CASE 45.-A male, aged 36, soon after an attack of pneumonia and pleurisy in 1945 noticed pain in his feet and hands. The proximal interphalangeal joints of the hands were painful and swollen. He had been treated as a case of rheumatoid arthritis and given two courses of gold with only slight improvement. He subsequently developed periodic attacks of pain and slight swelling in the joints of his hands and feet lasting for two or three days. Between the attacks he had always felt perfectly well. On .admission his general condition was satisfactory. There was slight muscle wasting of the forearms and the interossei muscles. The epitrochlear glands were enlarged. He had never lost any weight. The joints were symmetrically involved; the knees, hips, and ankles were not affected. The haematocrit had always been normal, and several estimations of the sedimentation rate had given normal figures. The plasma uric acid had fluctuated between 4.4 and $6.7 \mathrm{mg}$. per cent. $X$-rays of the hands showed no osteoporosis, but numerous translucent areas of gouty type. He responded well to colchicine therapy. A muscle biopsy from the right vastus externus, which was not wasted, showed mild degenerative muscle changes only. No vascular disease was present and no round-cell foci of rheumatoid type were seen.

Osteo-Arthritis.-Seven cases of osteo-arthritis of the hip joint were investigated. In six cases the result was negative, but in one changes were found which were suggestive of a rheumatoid reaction. 
CASE 96.-A male, aged 63, with osteo-arthritic changes of the left hip superadded on congenital shortening of the left leg gave no history or clinical evidence of rheumatoid arthritis. There was no anaemia, and the sedimentation rate was normal (C.S.S. 82 per cent.) The plasma uric acid was $6.1 \mathrm{mg}$. per cent.

On section the muscle fibres showed very slight degenerative changes. The small arterioles had thickened walls but the patient's age might account for this. In two areas in one section examined, but not in further sections made at different levels in the same block, small cellular accumulations were seen. They consisted of large mononuclear cells of endothelial type with a few lymphocytes and some proliferation of local fibrous tissue cells and sarcolemma nuclei. Both were in relation to capillary vessels between the muscle fibres. They were similar in appearance to the smaller foci found in rheumatoid arthritis but were not quite typical.

Non-rheumatic Cases.-Muscle from three cases of poliomyelitis failed to show any lesion of the "rheumatoid" type. Degenerative changes and fibrous replacement were the only features to be seen.

Three cases were seen of specific infective arthritis -a streptococcal arthritis of the right knee, a tuberculous arthritis of the knee, and a chronic osteomyelitis. In the latter the muscle examined was adherent to the bone focus and also showed degeneration and fibrosis of varying degrees, but - no round-cell foci.

A case of Paget's disease and one of prolapsed intervertebral disc were also negative. A muscle sample taken from the left supraspinatus of a case of fibrositis showed thickening of the fascial covering of the muscle with some sclerosis of the arterioles in the fibrous tissue, but no round-cell foci.

Muscle from a case of Volkmann's ischaemia showed a diffuse round-cell infiltration in the fibrous tissue among muscle fibres. The cells were not related to blood vessels as in rheumatoid arthritis and were scattered throughout the area (Fig. 3).

The quadriceps muscle from a case of tuberculosis of the spine with paraplegia and marked wasting of the lower limbs showed a few lymphocytes in small foci near blood vessels (Fig. 4). This specimen is included here as an example of roundcell reaction in what is probably a purely trophic wasting of muscle.

In a case of chronic myositis of unknown aetiology the muscle fibres were shrunken and atrophic and were surrounded by loose fibrous tissue. Around the vessels there were localized round-cell foci consisting of lymphocytes, plasma cells, and a few polymorphs (Fig. 5).

Two cases were found in which a rheumatoid pathology might have been diagnosed if an isolated field only had been examined.
Following a left mastectomy in a woman, aged 47, a small nodule appeared in the region of the operation scar. Seven months after the first operation, this was excised together with some of the underlying muscle. The main mass consisted of small foreign bodies with accompanying fibrous and giant-cell reaction ; "foam cells" and cholesterol clefts were present. In the underlying muscle at some distance from the main nodule there were focal accumulations of lymphocytes resembling closely those seen in rheumatoid arthritis (Fig. 6).

Following a fall seven months previously a woman, aged 52, was admitted with a fusiform, painless swelling over the upper end of the left femur. Biopsy showed fibrosis of the muscle with degeneration and shrinkage of the fibres. The blood vessels showed perivascular round-cell reaction involving the adventitial coat. Certain fields showed round-cell foci among the muscle fibres, in some respects similar to those of rheumatoid arthritis. The cells present were mainly lymphocytes, with a few plasma cells, polymorphs, and large mononuclear cells. This condition was regarded as a post-traumatic chronic inflammatory reaction in the muscle.

Muscle from a case of amyotonia congenita showed the typical histology of that condition, but no round-cell foci were present.

\section{Discussion}

1. No relationship was found between the incidence of positive biopsies and the activity of the arthritis. Lesions were present in cases of from one to twenty-four years' duration, but the chances of finding a typical reaction in the muscles increased with the duration of the disease process.

2. Muscle biopsy appears to be of value in difficult cases. A positive finding would be strongly in favour of a diagnosis of non-specific polyarthritis.

3. The other positive histo-pathological changes in the synovia, skin and subcutaneous nodules, and the reaction taking place in relation to blood vessels of the fibrous supporting tissues suggest that the muscle lesions are only a part of a widely distributed mesodermal reaction.

4. The fact that the lesions were found in apparently healthy muscles not related to affected joints and in such small specimens of muscle selected at random is evidence of the widespread nature of the reaction and also that the muscle lesions were not secondary to muscle wasting or local joint disease. Their absence in cases of specific infective arthritis is evidence that they are probably not secondary to joint disease per se.

5. Further evidence that rheumatoid arthritis and 
spondylitis ankylopoietica are two different diseases is afforded by the absence of a single positive biopsy in sixteen cases of ankylosing spondylitis.

\section{Summary}

Recent literature on the histo-pathology of nonarticular tissue in rheumatoid arthritis is reviewed.

Examination of muscles obtained either by biopsy or at operation was carried out on a series of fifty-six typical cases of idiopathic rheumatoid arthritis, five cases of non-specific infective arthritis, forty-three cases of other rheumatic conditions, and fifteen non-rheumatic controls. Of the fifty-six cases of typical idiopathic rheumatoid arthritis investigated, 34 (60.7 per cent.) showed round-cell foci and thickening of the walls of the blood vessels.

The changes in the muscles were present both in cases in which the disease was active and in those which appeared clinically quiescent or " burnt out".

The lesions were found in cases with and without muscle wasting.

Muscle remote from affected joints also showed the typical lesions.

No typical rheumatoid changes were found in cases of less than six months' duration. In those examined within three years, seven years, and from eight years onwards the chances of finding the lesions were 47 per cent., 60 per cent., and 82 per cent. respectively.

Seventeen out of the thirty-four cases of typical idiopathic rheumatoid arthritis with positive muscle findings showed other positive histological changes either in the synovia, skin, or subcutaneous nodules. Four cases with negative findings in the muscle showed typical changes in other mesodermal tissues.

Of four cases of rheumatoid arthritis associated with psoriasis, one case gave a positive muscle finding.

Five cases of chronic polyarthritis with a past history of a gonococcal urethritis, and two cases of typical gonococcal arthritis all gave negative results on biopsy.

Of three cases of Still's disease, two failed to show muscle changes; one case showed highly characteristic round-cell foci, and another showed lesions in the skin.

Lesions were found in the muscles in one out of four cases of rheumatoid arthritis with a past history of rheumatic fever.

Four cases of subacute rheumatic infection with a past history of rheumatic fever gave negative muscle findings. One case, however, showed changes in the skin.

One case of rheumatic fever showed no change in the muscles.
The muscle lesion was found in one of five cases of non-specific infective arthritis. The synovia in three of these cases showed changes consistent with rheumatoid arthritis.

Muscle biopsies in seventeen cases of spondylitis ankylopoietica were examined. All gave negative results.

Muscle examined from six cases of typical gout were all negative.

Seven cases of osteo-arthritis of the hip joint were examined. In six the results were negative, but in one case changes were found which were suggestive of a rheumatoid reaction.

Muscle from fifteen non-rheumatic controls were examined. This group consisted of the following cases: three of poliomyelitis; three of specific infective arthritis; one of Paget's disease; one of prolapsed intervertebral disc; one of fibrositis. All these cases gave negative results.

Among cases showing lesions in muscle which resembled in some respects those seen in rheumatoid arthritis were one example each of the following conditions : Volkmann's ischaemia ; atrophic muscle following tuberculosis of the spine, with paraplegia; chronic myositis of unknown origin; breast tumour showing foreign-body reaction; post-traumatic myositis.

We should like to express our thanks to the Sidney Robinson Research Fund for assistance in defraying expenses in connexion with this work, to the remainder of hospital staff of the Royal National Hospital for Rheumatic Diseases for giving us access to cases under their care, and in particular to Mr. Bastow for supplying us with material from cases operated on at other hospitals.

\section{REFERENCES}

Bennett, G. A. (1941). J. Amer. med. Ass., 117, 1647.

Collins, D. H. (1940). Annals of the Rheumatic Diseases, 2, 114.

Curtis, A. C., and Pollard, H. M. (1940). Ann. intern. Med., 13, 2265.

Forest de, G. K., Bunting, H., and Kenney, W. E. (1947). Annals of the Rheumatic Diseases, 6, 86.

Freund, H. A., Steiner, G., Leichtentritt, B., and Price A. E. (1945). Science, 101, 202.

Gibson, H. J., Kersley, G. D., and Desmarais, M. H. L. (1946). Annals of the Rheumatic Diseases, 5, 131

Kersley, G. D., Gibson, H. J., and Desmarais, M. H. L. (1946). Ibid., 5, 141.

McEwen, C., Bergmann, E. W., and Most, H. (1941). J. Amer. med. Ass., 117, 1646.

\section{Histologie du Muscle chez des Rhumatisants et des Sujets Normaux \\ RÉSUMÉ}

Les auteurs passent en revue les publications récentes sur l'histologie pathologique des tissus articulaires dans l'arthrite rhumatismale. 
Des muscles obtenus soit par biopsie soit à la suite d'opérations ont été examinés sur une série de cinquantesix cas d'arthrite rhumatismale idiopathique typique, cinq cas d'arthrite infectieuse non spécifique, et quarantetrois cas d'autres affections rhumatismales, et sur quinze sujets non rhumatisants. Sur les cinquante-six cas d'arthrite rhumatismale idiopathique typique, 34 (60.7 pour cent) présentaient des foyers globo-cellulaires et un épaississement des parois vasculaires.

Les altérations musculaires étaient présentes aussi bien dans les cas où la maladie était en pleine activité que dans ceux où elle semblait cliniquement latente.

On a observé ces lésions aussi bien chez les sujets atteints d'atrophie musculaire que chez ceux qui n'en présentaient pas.

Ces lésions typiques étaient également présentes sur les biopsies pratiquées loin des articulations atteintes.

On n'a observé aucune altération rhumatismale typique chez les sujets atteints depuis moins de six mois. Chez les sujets étudiés au bout de trois ans, sept ans, et huit ans et au-delà, les chances de trouver des lésions étaient respectivement 47,60 , et 82 pour cent.

Sur les trente-quatre cas d'arthrite rhumatismale idiopathique typique avec lésions musculaires, dix-sept présentaient d'autres lésions histologiques positives de la membrane synoviale, de la peau, ou des nodules souscutanés. Quatre cas sans lésions musculaires présentaient des altérations typiques d'autres tissus d'origine mésodermique.

Sur quatre cas d'arthrite rhumatismale accompagnée de psoriasis, un seul cas présentait des lésions musculaires.

Cinq cas de polyarthrite chronique avec des antécédents d'uréthrite gonococcique, et deux cas d'arthrite gonococcique typique ont tous donné des biopsies négatives.

Sur trois cas de syndrome de Still-Felty, deux ne présentaient aucune lésion musculaire; un seul pré- sentait des foyers globo-cellulaires nettement caractéristiques, et un autre des lésions cutanées:

Sur quatre cas d'arthite rhumatismale avec antécédents de rhumatisme articulaire aigu, on n'a trouvé de lésions musculaires que dans un seul cas.

Quatre cas d'infection rhumatismale subaiguë avec antécédents de rhumatisme articulaire aigu ont donné des résultats négatifs. L'un des malades présentait cependant des lésions cutanées.

Un cas de rhumatisme articulaire aigu ne présentait aucune lésion musculaire.

On a observé la lésion musculaire typique dans un cas d'arthrite infectieuse non spécifique sur cinq étudiés. Chez trois de ces sujets la membrane synoviale présentait des modifications cohérentes avec l'arthrite rhumatismale.

Les examens de biopsies de muscles dans dix-sept cas de spondylite ankylosante ont tous donné des résultats négatifs.

Six cas de goutte n'ont présenté aucune lésion musculaire.

On a étudié sept cas d'arthrite ostéo-articulaire de la hanche. Six ont donné des résultats négatifs mais on a trouvé chez un malade des lésions suggérant une réaction rhumatismale.

On a examiné des muscles de quinze sujets témoins non rhumatisants. Ce groupe était constitué par les cas suivants: trois cas de poliomyélite; trois cas d'arthrite spécifique infectieuse; un cas de maladie de Paget; un cas de déplacement de disque intervértébral; un cas de cellulite. Tous ont donné des résultats négatifs.

Parmi les sujets qui présentent des lésions musculaires ressemblant de près ou de loin à celles de l'arthrite rhumatismale, se trouvait un exemple de chacune des affections suivantes: paralysie ischémique de Volkmann; atrophie musculaire après tuberculose vertébrale, avec paraplégie; myosite chronique d'origine inconnue; tumeur du sein simulant un corps étranger; myosite post-traumatique. 